\title{
Antidiabetic and antioxidant properties of Ficus deltoidea fruit extracts and fractions
}

\author{
Hasni Misbah ${ }^{1}$ Azlina Abdul Aziz ${ }^{2}$ and Norhaniza Aminudin ${ }^{3^{*}}$
}

\begin{abstract}
Background: Diabetes is a serious metabolic disorder affecting the metabolism of carbohydrate, protein and fat. A number of studies have shown that diabetes mellitus is associated with oxidative stress, leading to an increased production of reactive oxygen species. Ficus deltoidea is traditionally used in Malaysia for regulating blood sugar, blood pressure and cholesterol levels. The use of $F$. deltoidea as an alternative medicinal herb is increasingly gaining popularity with the sale of $F$. deltoidea tea bags and capsules in the local market. The present study was undertaken to investigate the antidiabetic and antioxidant activities of the fruits from different varieties of $F$. deltoidea, employing in vitro methods.
\end{abstract}

Method: Two fruit varieties of F. deltoidea (var. angustifolia (SF) and var. kunstleri (BF)) were extracted separately using double-distilled water. The resulting aqueous extracts were partitioned using ethyl acetate to obtain the ethyl acetate and water fractions. The crude aqueous extracts and the corresponding fractions were evaluated for their phenolic, flavonoid, sugar and protein contents. Protein profiling of the extracts and fractions were also carried out by means of SDS-PAGE and SELDI-TOF MS. Antidiabetic activities were assessed based on the ability of the samples to inhibit yeast and mammalian a-glucosidase as well as a-amylase. Antioxidant capacities were examined by measuring the ability of the samples to reduce ferric ions and to scavenge DPPH, superoxide anion, ABTS and nitric oxide radicals.

Results: The crude extracts and fractions of SF and BF inhibited both yeast and rat intestinal a-glucosidases in a dose-dependent manner, but did not inhibit porcine pancreatic a-amylase. The water fraction of BF showed the highest percentage of a-glucosidase inhibition while having the highest amount of protein $(73.33 \pm 4.99 \mu \mathrm{g} / \mathrm{mg}$ fraction). All the extracts and fractions exhibited antioxidant activities, with SF crude extract showing the highest antioxidant activity and phenolic content $(121.62 \pm 4.86 \mathrm{mg} / \mathrm{g}$ extract). Fractionation of the crude extracts resulted in loss of antioxidant activities. There was no positive correlation between phenolic and flavonoid content with a-glucosidase inhibitory activities. However, phenolic content correlated well with antioxidant activities of the crude extracts but not with the fractions.

Conclusions: The antioxidant activities of the fruits of $F$. deltoidea might be asserted by the phenolic content but other polar plant components were possibly involved in the antidiabetic properties. The study of these compounds having both antihyperglycemic and antioxidant activities may provide a new approach in the treatment of diabetes mellitus.

Keywords: Antioxidant, Diabetes, Ficus deltoidea, Phenolic, SDS-PAGE, SELDI-TOF MS

\footnotetext{
* Correspondence: hanizaaminudin@um.edu.my

${ }^{3}$ Institute of Biological Sciences, Faculty of Science, University of Malaya,

50603, Kuala Lumpur, Malaysia

Full list of author information is available at the end of the article
} 


\section{Background}

Diabetes mellitus is a metabolic disease characterized by hyperglycemia and disturbances in fat and protein metabolism that results from defects in both insulin secretion and/or insulin action [1]. Various pharmacological approaches have been used to improve diabetes via different modes of action including stimulation of insulin release, inhibition of gluconeogenesis, increasing the number of glucose transporters and reduction of glucose absorption from the intestine [2]. One of the beneficial therapies to impair glucose absorption is through the inhibition of carbohydrate hydrolyzing enzymes such as $\alpha$ amylase and $\alpha$-glucosidase in the digestive organs [3,4]. Inhibitors of these enzymes delay carbohydrate digestion and prolong the overall time for carbohydrate digestion, resulting in a decrease in the rate of glucose absorption [5]. Increasing evidence has shown that prolonged exposure to elevated glucose induces the production of free radicals, particularly reactive oxygen species (ROS), through glucose auto-oxidation and protein glycosylation [6]. Oxidative injury by ROS has been suggested to explain the excess prevalence of vascular complications in diabetes mellitus, which may be mediated by oxidative stress $[7,8]$. An impairment in the equilibrium between ROS and antioxidants results in oxidative stress, a deleterious process that can be an important mediator of damage to cell structures, including lipids and membranes, proteins and DNA. Indeed, a variety of defects in antioxidative status have been reported in experimental and in diabetic patients when compared with normal population $[9,10]$.

Traditional medicinal plants have been used for many years by different cultures around the world for the management of diabetes. In recent years, investigation on herbal medicines has become progressively important in the search for a new, effective and safe therapeutic agent for the treatment of diabetes. More than 200 pure bioactive principles isolated from plants have been demonstrated to have blood glucose-lowering effect [11], several of which are phenolics [12], flavonoids [13,14], triterpenoids, alkaloids [15-17] and carbohydrates [18]. Ficus deltoidea, a plant belonging to the Moraceae family or locally known as "Mas Cotek" is a new potential medicinal plant in Malaysia. Little is known about the chemical constituents of $F$. deltoidea but some of the compounds claimed to be present in $F$. deltoidea are the flavonoids isovitexin, vitexin $[19,20]$, proanthocyanidins, flavan-3-ol monomers and flavones glycosides [21]. Recently, a study by Zainah and collegues proposed that the aqueous extract of $F$. deltoidea leaves might contain water-soluble insulin-secreting constituents with better insulin secretion activity than a well-known hypoglycaemic agent, glibenclamide [22]. Interestingly, a toxicological study on $F$. deltoidea reported that the plant does not contain toxic components [23]. The leaves of $F$. deltoidea have been shown to exhibit blood glucose-lowering effects [19,20,22,24-26], antinociceptive [27], ulcer healing [28], antioxidant [19,21,29,30], antiinflammatory [31] and antimelanogenic [32] properties. However, to date, there is no available report on the pharmacological activities of the fruits of $F$. deltoidea. Therefore, the present study attempts to investigate the potential antidiabetic and antioxidant activities of two different fruit varieties from $F$. deltoidea (var. angustifolia (SF) and var. kunstleri (BF)) in order to develop a physiological functional food for use as antidiabetic agents.

\section{Methods}

\section{Chemicals}

$p$-Nitrophenyl $\alpha$-D-glucopyranoside ( $p$ NPG), Baker's yeast $\alpha$-glucosidase, rat intestinal acetone powder, acarbose, 3,5-dinitrosalicylic acid, sucrose, $D$-(+)-glucose, 2,2-diphenyl-1-picrylhydrazyl (DPPH), 6-hydroxy-2,5,7,8tetramethylchroman-2-carboxylic acid (Trolox), sodium carbonate, ferric chloride, ferrous sulphate, aluminium chloride, polyvinylpyrrolidone, Folin-Ciocalteau's phenol reagent, gallic acid, quercetin, Acrylamide PAGE, 2mercaptoethanol and ammonium sulphate were purchased from Sigma Chemical Co. (St. Louis, MO, USA). Protein assay reagent, bovine serum albumin and polypeptide standard were from Bio-Rad Laboratories (USA). Glucose oxidase kit was from Megazyme International (Ireland). All other chemicals used in this study were of analytical grade.

\section{Plant materials}

The fruits of $F$. deltoidea were collected from Delto Medicama Plantation (M) Sdn Bhd., Sabak Bernam, Selangor, Malaysia. These samples included fruits from F. deltoidea var. angustifolia (SF) (voucher specimen: KLU 046467) and F. deltoidea var. kunstleri (BF) (voucher specimen: KLU 046470) were identified by the corresponding author. The fruits were cleaned, air-dried, cut into small pieces and then pulverized. Samples were deposited in the Herbarium, Rimba Ilmu, University of Malaya.

\section{Preparation of crude extract and fractions}

The dried fruit powder of F. deltoidea $(100 \mathrm{~g})$ was boiled in $1 \mathrm{~L}$ of distilled water for 2 hours. At the end of the 2 hour boiling period, the same volume of distilled water was added and the boiling procedure was continued for another 2 hours. The crude aqueous extract was filtered, centrifuged and freeze-dried to yield the lyophilized crude aqueous extracts. Five gram of the crude aqueous extract was dissolved in $50 \mathrm{ml}$ of distilled water and partitioned with $100 \mathrm{ml}$ of ethyl acetate in a separating 
funnel. The solution was allowed to stand for 2 hours for complete solvent-water separation. The bottom aqueous layer was collected and freeze-dried, to obtain the water fraction which was free from nonpolar compounds. The ethyl acetate upper layer was then evaporated using rotary evaporator to yield the ethyl acetate fraction.

\section{Phytochemical screening Determination of phenolic content}

The phenolic content of the extracts was determined through the Folin-Ciocalteu assay developed by Singleton and Rossi [33]. Briefly, $10 \mu \mathrm{l}$ of $1 \mathrm{mg} / \mathrm{ml}$ crude aqueous extracts or fractions were mixed with $450 \mu \mathrm{l}$ of distilled water and $2.5 \mathrm{ml}$ of $0.2 \mathrm{~N}$ Folin-Ciocalteu reagent. After $5 \mathrm{~min}, 2 \mathrm{ml}$ of $10 \%$ sodium carbonate was added. The absorbance of the resulting blue-coloured solution was measured at $765 \mathrm{~nm}$ after incubation at $37^{\circ} \mathrm{C}$ for $30 \mathrm{~min}$. Gallic acid was used as standard and phenolic content was expressed as milligram gallic acid equivalents (GAE) per gram of dried extract/fraction.

\section{Determination of flavonoid content}

Five hundred microlitres of $1 \mathrm{mg} / \mathrm{ml}$ crude aqueous extracts or fractions were mixed with $1.5 \mathrm{ml}$ of $95 \%$ ethanol, $0.1 \mathrm{ml}$ of $10 \%$ aluminum chloride hexahydrate, 0.1 $\mathrm{ml}$ of $1 \mathrm{M}$ potassium acetate and $2.8 \mathrm{ml}$ of deionized water. After incubation at room temperature for $30 \mathrm{~min}$, the absorbance of the reaction mixture was measured at $415 \mathrm{~nm}$. Quercetin was used as standard and the results were expressed as milligram quercetin equivalents (QE) per gram dried extract/fraction.

\section{Determination of total sugar content}

The sugar content in the crude aqueous extracts and water fractions were determined according to DuBois et al. [34], using a slightly modified phenol-sulphuric acid method. The reaction was initiated by mixing $200 \mu \mathrm{l}$ of crude extract (or fraction) with $200 \mu \mathrm{l}$ of $5 \%$ phenol in a test tube, followed by the addition of $2 \mathrm{ml}$ of concentrated sulphuric acid. The tube was placed in hot water and kept at $90^{\circ} \mathrm{C}$ for $5 \mathrm{~min}$. After cooling to room temperature, the absorbance of the mixture was measured at $490 \mathrm{~nm}$. A series of $D$-(+)-glucose concentrations was analysed as above to develop a calibration curve. Total sugar content was calculated based on the curve, and expressed as glucose equivalents (GE) in $\mu \mathrm{mol} / \mathrm{g}$ of dried extract or fraction.

\section{Determination of protein content}

Protein content of the crude aqueous extracts and water fractions were determined by Bradford protein assay with bovine serum albumin (BSA) as the standard [35]. Five microlitres of sample (or standard) was mixed with
$250 \mu \mathrm{l}$ of Bradford reagent and allowed to stand in the dark, at room temperature. After $15 \mathrm{~min}$, the absorbance of each sample or standard was measured at $595 \mathrm{~nm}$ against a blank.

\section{In vitro antidiabetic assays \\ Yeast a-glucosidase inhibition assay}

The enzymatic activities of $\alpha$-glucosidase were determined colorimetrically by monitoring the release of 4-nitrophenol from 4-nitrophenyl- $\alpha$ - $D$-glucopyranoside $(p N P G)$. Crude aqueous extracts and water fractions were dissolved in distilled water to give six concentrations while the ethyl acetate fractions were prepared using DMSO. The aqueous extracts and fractions $(125 \mu \mathrm{l})$ were pre-incubated with $250 \mu \mathrm{l}$ of $0.1 \mathrm{U} / \mathrm{ml} \alpha$ glucosidase at $37^{\circ} \mathrm{C}$ for $5 \mathrm{~min}$. On the other hand, $25 \mu \mathrm{l}$ of the ethyl acetate fraction was mixed with 100 of distilled water before pre-incubation with the enzyme solution. The reaction was initiated by adding $125 \mu \mathrm{l}$ of freshly prepared $p$ NPG to the mixture followed by 30 min incubation at $37^{\circ} \mathrm{C}$. Reaction was terminated by the addition of $1 \mathrm{ml}$ of $0.1 \mathrm{M} \mathrm{Na}_{2} \mathrm{CO}_{3}$. Assays using acarbose as the positive control were also carried out as above. Absorbance values were recorded at $405 \mathrm{~nm}$ and the $\alpha$-glucosidase inhibitory activity (\%) was calculated as follows:

$$
\% \text { inhibition }=\frac{\mathrm{Abs}_{\mathrm{control}}-\mathrm{Abs}_{\text {extract }}}{\mathrm{Abs}_{\text {control }}} \times 100
$$

The $\mathrm{IC}_{50}$ value, defined as the concentration of the samples causing $50 \%$ inhibition of $\alpha$-glucosidase was estimated by non-linear regression analysis using Graph Pad Prism software.

\section{Rat intestinal a-glucosidase inhibition assay}

The inhibitory activity of $F$. deltoidea against $\alpha$ glucosidase was determined using sucrose and $4 \mathrm{mM}$ $p$ NPG, and as the substrates. The reaction mixture consisted of $50 \mu \mathrm{l}$ of the extract or fraction, $25 \mu \mathrm{l}$ of enzyme solution and $50 \mu \mathrm{l}$ of sodium phosphate buffer in a tube. Acarbose was used as the positive control. After 5 min of pre-incubation at $37^{\circ} \mathrm{C}$, reaction was initiated by adding $50 \mu \mathrm{l}$ of $50 \mathrm{mM}$ sucrose or $4 \mathrm{mM} p$ NPG. The mixture was further incubated at $37^{\circ} \mathrm{C}$ for $45 \mathrm{~min}$ (sucrose) or $30 \mathrm{~min}(p \mathrm{NPG})$. Reaction was terminated by adding $0.25 \mathrm{ml}$ of $0.1 \mathrm{M}$ of $\mathrm{Na}_{2} \mathrm{CO}_{3}$ and the release of $p$-nitrophenol from $p$ NPG was measured at $405 \mathrm{~nm}$. When sucrose was used as the substrate, reaction was stopped by incubating each tube in boiling water bath for 5 minutes. The concentrations of glucose released from sucrose were determined by mixing $250 \mu \mathrm{l}$ of the solution with glucose oxidase reagent. After $20 \mathrm{~min}$ of incubation, absorbance was read at $415 \mathrm{~nm}$. Inhibition 
rates were calculated based on the previous equation and the $\mathrm{IC}_{50}$ values were determined. All experiments were carried out in triplicates and the results are expressed as the mean \pm S.D. of three determinations.

\section{a-amylase inhibition assay}

The crude aqueous extracts and fractions $(125 \mu \mathrm{l})$ with different concentrations were incubated with $125 \mu \mathrm{l}$ of $\alpha$-amylase solution ( $1 \mathrm{U} / \mathrm{ml}$ phosphate buffer) at $37^{\circ} \mathrm{C}$ for $10 \mathrm{~min}$. After pre-incubation, $125 \mu \mathrm{l}$ of $0.5 \%$ starch solution was added into the tube and further incubated for $30 \mathrm{~min}$. The reaction was stopped by the addition of $250 \mu \mathrm{l}$ of dinitrosalicylic acid reagent and immediately tubes were incubated for $5 \mathrm{~min}$ in a boiling water bath. Once cooled to room temperature, the mixture was diluted with $1.5 \mathrm{ml}$ of distilled water and the absorbance was measured at $540 \mathrm{~nm}$. Acarbose was used in the assay as a positive control. The percentage of $\alpha$-amylase inhibition and $\mathrm{IC}_{50}$ value were calculated using the same equation as for $\alpha$-glucosidase inhibition.

\section{In vitro antioxidant assays}

\section{2, 2-diphenyl-1-picrylhydrazyl (DPPH) radical scavenging activity}

The scavenging activity of the stable free radical, DPPH. was determined according to the method described by Braca et al. [36]. DPPH solution was prepared by diluting $20 \mu \mathrm{l}$ of DPPH stock solution $(2 \mathrm{mg} / \mathrm{ml}$ methanol) with $0.98 \mathrm{ml}$ of methanol. Samples were added to the diluted DPPH solution in a 1:6, volume to volume ratio. A series of concentrations ranging from 25 to $1000 \mu \mathrm{g} / \mathrm{ml}$ samples were tested. The mixtures were shaken vigorously and incubated in the dark for 30 min after which the reduction of DPPH • absorption was measured at 517 $\mathrm{nm}$. The percentage of inhibition was calculated according to the following equation:

$$
\% \text { inhibition }=\frac{\mathrm{Abs}_{\mathrm{control}}-\mathrm{Abs}_{\text {extract }}}{\mathrm{Abs}_{\text {control }}} \times 100
$$

Quercetin was used as a positive control. Scavenging activity of the plant extracts was estimated based on the percentage of the DPPH - reduction by calculating the $\mathrm{IC}_{50}$ values of $\mathrm{DPPH}$ radicals using a non-linear regression analysis.

\section{Ferric reducing ability of plasma (FRAP) assay}

The ferric reducing activity of the plant samples was estimated based on the ferric reducing ability of plasma (FRAP) procedure described by Benzie and Strain [37]. Working FRAP reagent was prepared by mixing $25 \mathrm{ml}$ acetate buffer, $2.5 \mathrm{ml} \mathrm{2,} \mathrm{4,} \mathrm{6-tripyridyl-s-triazine} \mathrm{(TPTZ)}$ solution and $2.5 \mathrm{ml}$ of $\mathrm{FeCl}_{3} \cdot 6 \mathrm{H}_{2} \mathrm{O}$ solution. The assay was performed by incubating the freshly prepared FRAP reagent at $37^{\circ} \mathrm{C}$ for $5 \mathrm{~min}$ and the blank reading was taken at $593 \mathrm{~nm}$. Thereafter, crude aqueous extracts, fractions, or standard along with distilled water was added to the FRAP reagent at a ratio of 1:3:30 (volume to volume), respectively. Absorbance was recorded at 0 sec immediately upon addition of the FRAP reagent and every $15 \mathrm{sec}$ for $4 \mathrm{~min}$. The assay was repeated using varying concentrations of $\mathrm{FeSO}_{4} \cdot 7 \mathrm{H}_{2} \mathrm{O}$ to construct the standard curve. Calculated FRAP values were expressed as mmol ferric ions reduced by the samples to the ferrous form, per gram of dried extract/fraction. Quercetin was used as positive control.

\section{Superoxide anion radical scavenging activity}

Superoxide anion radical scavenging activity was performed according to the method of Nikishimi and colleagues [38]. Superoxide radicals were determined by the phenazine methosulphate (PMS)-NADH superoxide generating system. The reaction mixture contained $25 \mu \mathrm{l}$ of sample, $50 \mu \mathrm{l}$ of nitroblue tetrazolium (NBT), $50 \mu \mathrm{l}$ of NADH and $50 \mu \mathrm{l}$ of $120 \mu \mathrm{M}$ PMS. NBT, NADH and PMS solutions were prepared in $0.1 \mathrm{M}$ sodium phosphate buffer $(\mathrm{pH}$ 7.4). The mixture was incubated at room temperature for $30 \mathrm{~min}$ and the absorbance read at $560 \mathrm{~nm}$. The decrease of absorbance at $560 \mathrm{~nm}$ was calculated as percentage of inhibition of NBT using the same equation as the DPPH assay and expressed as mg of Trolox equivalent (TE) per gram of dried aqueous extract/fraction. Quercetin was used as positive control.

\section{2, 2'-azinobis (3-ethylbenzothiazolinesulphonic acid) (ABTS) radical scavenging activity}

The ABTS radical cation $\left(\mathrm{ABTS}^{\bullet+}\right)$ was generated by mixing equal volume of ABTS solution and potassium persulfate, and allowing them to react for $12-16 \mathrm{~h}$ in the dark at room temperature. The solution was diluted with methanol to give an absorbance of $0.70( \pm 0.02)$ at 734 $\mathrm{nm}$ prior to use. Three microlitres of sample was reacted with $300 \mu \mathrm{l}$ of fresh $\mathrm{ABTS}^{*+}$ solution and absorbance was measured at $734 \mathrm{~nm}$ after $15 \mathrm{~min}$ incubation in the dark. Trolox standard curve was generated and the ABTS radical scavenging capacity was expressed as mmol Trolox equivalent (TE) per gram of dried aqueous extract/fraction. Quercetin was used as positive control.

\section{Nitric oxide radical scavenging activity}

Fifty microlitres of sample was mixed with $200 \mu \mathrm{l}$ of SNP in PBS and was incubated in the dark at room temperature. After $150 \mathrm{~min}, 25 \mu \mathrm{l}$ of Griess reagent was added to the reaction mixture and further incubated for $30 \mathrm{~min}$. The pink chromophore generated during diazotization of nitrite ions with sulphanilamide and subsequent coupling with NED was measured spectrophotometrically at $540 \mathrm{~nm}$ against a blank sample. 
Results were expressed as percentage inhibition of the nitric oxide radicals. The nitric oxide radical scavenging activity of the extracts was also measured using the Trolox standard curve and results were expressed as mmole Trolox equivalent (TE) antioxidant capacity per gram of dried extract/fraction.

Sodium dodecyl sulfate-polyacrylamide gel electrophoresis (SDS-PAGE) analyses The crude aqueous extracts and water fractions were treated with $1 \%$ insoluble polyvinylpyrrolidone (PVP) and stirred continuously at $4^{\circ} \mathrm{C}$ for 4 hours. PVP-bound phenolics were removed by centrifugation at $10000 \mathrm{rpm}$ and the supernatant was next precipitated with ammonium sulfate $(90 \%$ saturation) at room temperature. Following centrifugation at $10000 \mathrm{rpm}$, the precipitated proteins were dissolved in $5 \mathrm{ml}$ distilled water and dialyzed against distilled water $\left(4^{\circ} \mathrm{C}, 48 \mathrm{~h}\right.$, three changes). Protein precipitation was furthered using cold acetone according to the method of Sindhu et al. [39]. The final protein content in the sample solutions was quantified and then lyophilized before storage at $-20^{\circ} \mathrm{C}$. Proteins were analyzed by SDS-PAGE according to the method of Laemmli [40]. The crude extracts and water fractions containing $5 \mu \mathrm{g}$ protein, along with a peptide standard (MW 1.4-27 $\mathrm{kDa}$ ) were heated at $95^{\circ} \mathrm{C}$ for 4 minutes in SDS-PAGE sample buffer containing $5 \% \beta$-mercaptoethanol. Fifteen microlitre of samples and five microlitre of the marker were loaded into the sample wells of $4 \%$ stacking gel. Electrophoresis was performed using $18 \%$ Tris-tricine gel at an initial voltage of $60 \mathrm{~V}$ for $10 \mathrm{~min}$ and then increased to a constant voltage at $150 \mathrm{~V}$, once samples had entered the separating gel. The bands were visualized by silver staining and the relative mobility $\left(R_{f}\right)$ of each band in the standards and the samples was calculated using the following equation:

$$
\mathrm{R}_{\mathrm{f}}=\frac{\text { Distance }(\text { in } \mathrm{mm}) \text { protein migrated }}{\text { Distance }(\text { in } \mathrm{mm}) \text { of Coomassie blue dye front }}
$$

Using the molecular weight of protein standards, log MW (y-axis) versus $\mathrm{R}_{\mathrm{f}}$ ( $\mathrm{x}$-axis) was plotted to generate a calibration curve against which the molecular weight of unknown protein samples were determined.

Surface enhanced laser desorption/ionization timeof-flight mass spectrometry (SELDI-TOF MS) All ProteinChip arrays were pre-treated according to manufacturer instructions. The reversed-phase hydrophobic surface ProteinChip array (H50) were applied with $2.5 \mu \mathrm{l}$ binding buffer $(0.5 \%$ trifluoroacetic acid $/ 50 \%$ acetonitrile) and allowed to air dry. Four microlitre of sample (1 $\mathrm{mg} / \mathrm{ml})$, was applied to each spot and the array was incubated at room temperature for $30 \mathrm{~min}$. Next, $2 \mu \mathrm{l}$ of concentrated matrix solution (7 mg $\alpha$-cyano-4hydroxycinnamic acid/ml binding buffer) was added to each spot. The ProteinChip array was air-dried (30 min) and analysed in a ProteinChip Reader (BioRad Laboratories, USA). Each sample was bound to each array surface in triplicate. The SELDI analysis was performed according to the protocol of Lau and colleagues [41].

\section{Statistical analysis}

All experimental results were expressed as means of triplicate analysis \pm standard deviations. Differences between groups were analysed using Student's $t$-test on theMicrosoft Excel software. Correlation analyses were calculated using Pearson correlation analysis SPSS software, version 17 (SPSS Inc., Chicago, IL). A value of $p<0.05$ was considered statistically significant.

\section{Results}

\section{Phenolic and flavonoid content}

Phenolic compounds are secondary metabolites ubiquitously found in plants, mainly acting as UV protectors. For both varieties, the crude extracts (C) showed the highest phenolic content compared to the fractions (Table 1). Following fractionation, the water fractions (W) from both varieties showed higher phenolic content than the ethyl acetate fractions (E). Flavonoid content was higher in the crude extract of var. angustifolia (SFC) and its fractionation led to higher flavonoids in the ethyl acetate fraction (SFE) compared to the water fraction $(\mathrm{SFW})$. In contrast, the ethyl acetate fraction of var. kunstleri (BFE) had higher flavonoid content than the corresponding crude extract. Statistical analyses showed that there were significant differences in phenolic content between extracts and the fractions of the same variety $(p<0.01)$.

\section{Estimation of sugar and protein contents}

As shown in Table 1, both SFC and BFC contained almost similar concentrations of sugar. Fractionation slightly reduced the sugar content of SFW while there was no significant difference in the sugar content between BFC and BFW. Apart from that, SFW and BFW contained more proteins than the corresponding crude extracts (Table 1 ) with only BF showing significant difference $(p<0.01)$.

\section{Inhibition of a-glucosidase activity}

The $\alpha$-glucosidase inhibitor potencies of extracts and fractions of the fruit varieties were compared on the basis of their $\mathrm{IC}_{50}$ values (Table 2). The BFW was the most potent inhibitor of yeast $\alpha$-glucosidase activity $(48.50 \pm 3.43 \mu \mathrm{g} / \mathrm{ml})$ when $p$-nitrophenyl- $\alpha$-D-glucopyranoside $(p \mathrm{NPG})$ was used as the substrate. BFC and its corresponding ethyl acetate fraction suppressed the activities 
Table 1 Phytochemical constituents of the crude aqueous extracts and fractions of the different fruit varieties of F. deltoidea

\begin{tabular}{|c|c|c|c|c|}
\hline F. deltoidea & $\begin{array}{l}\text { Total flavonoid content } \\
\text { (mg quercetin equivalents/g } \\
\text { dried extract/fraction) }\end{array}$ & $\begin{array}{l}\text { Total phenolic content } \\
\text { (mg gallic acid equivalents/g } \\
\text { dried extract/fraction) }\end{array}$ & $\begin{array}{l}\text { Sugar ( } \mu \mathrm{mol} \text { glucose/g } \\
\text { dried extract/fraction) }\end{array}$ & $\begin{array}{l}\text { Protein ( } \mu \mathrm{g} \text { protein/ } \\
\mathrm{mg} \text { dried extract/fraction) }\end{array}$ \\
\hline \multicolumn{5}{|c|}{ SF (var. angustifolia) } \\
\hline SFC & $17.34 \pm 0.63^{a}$ & $121.62 \pm 4.86^{f}$ & $2.58 \pm 0.03^{\prime}$ & $46.67 \pm 1.67^{p}$ \\
\hline SFE & $16.51 \pm 0.60^{a}$ & $47.09 \pm 1.68^{9}$ & ND & ND \\
\hline SFW & $12.37 \pm 1.15^{b}$ & $59.29 \pm 1.51^{h}$ & $1.83 \pm 0.05^{m}$ & $56.11 \pm 5.36^{p}$ \\
\hline \multicolumn{5}{|c|}{ BF (var. kunstleri) } \\
\hline BFC & $26.65 \pm 1.00^{c}$ & $96.89 \pm 2.57^{i}$ & $2.35 \pm 0.03^{n}$ & $57.78 \pm 3.85^{9}$ \\
\hline BFE & $12.31 \pm 2.19^{d}$ & $36.27 \pm 2.98^{j}$ & ND & ND \\
\hline BFW & $7.46 \pm 0.54^{e}$ & $90.62 \pm 1.27^{k}$ & $2.45 \pm 0.05^{n}$ & $73.33 \pm 4.99^{r}$ \\
\hline
\end{tabular}

Each value is expressed as a mean $\pm S D(n=3)$. Values with different superscript letters between the same variety, within the same column are significantly different at $p<0.01$. ND: not determined. SFC, SFE and SFW indicate crude aqueous extract, ethyl acetate fraction and water fraction of SF (var. angustifolia). BFC, $\mathrm{BFE}$ and BFW indicate crude aqueous extract, ethyl acetate fraction and water fraction of BF (var. kuntsleri).

of $\alpha$-glucosidase better than the SF samples. Acarbose, the positive control used in this study weakly inhibited yeast $\alpha$-glucosidase with $\mathrm{IC}_{50}$ value of $9.075 \pm 0.065 \mathrm{mg} /$ $\mathrm{ml}$. When crude mammalian $\alpha$-glucosidase was used, with sucrose as the substrate, the $\mathrm{IC}_{50}$ values were significantly increased. BFW again inhibited $\alpha$-glucosidase the most with $\mathrm{IC}_{50}$ value of $444.43 \pm 3.01 \mu \mathrm{g} / \mathrm{ml}$. When $p \mathrm{NPG}$ was used as the substrate for rat intestinal $\alpha$-glucosidase, the $\mathrm{IC}_{50}$ values further increased, suggesting its selective inhibition towards different substrate. The $\mathrm{IC}_{50}$ values of the positive control acarbose towards glycosidic bond cleavage of sucrose and $p$ NPG by rat intestinal $\alpha$-glucosidase were $39.45 \pm 0.499$ and $57.79 \pm 0.66 \mu \mathrm{g} / \mathrm{ml}$ respectively.

\section{a-amylase inhibitory activity}

Repeated $\alpha$-amylase assays however demonstrated that none of the extracts or the fractions exhibited inhibitory activity towards $\alpha$-amylase under the test condition. Acarbose however, strongly suppressed the activity of $\alpha$ amylase, giving an $\mathrm{IC}_{50}$ of $7.02 \pm 0.08 \mu \mathrm{g} / \mathrm{ml}$.

\section{Antioxidant activities}

Comparing the two varieties, SFC has better antioxidant activities than the BFC although their activities were lower than the positive control quercetin (Table 3). In general, both the crude extracts revealed greater antioxidant capabilities than the fractions. Following fractionation, antioxidant activities in SF and BF were found to be distributed between the two fractions.

\section{Correlation analyses}

Statistical analysis showed no correlation between phenolic and flavonoid content of the extracts and fractions $\left(\mathrm{r}^{2}<0.0216\right)$. No correlation was also observed between the $\alpha$-glucosidase inhibitory activities and both the phenolic $\left(\mathrm{r}^{2}<0.5837\right)$ and flavonoid $\left(\mathrm{r}^{2}<0.5459\right)$ content in the extracts and fractions. A significant positive correlation was seen between radical scavenging activities and phenolic content of the crude extracts but there was no correlation between antioxidant activities and the amount of flavonoids in the extracts or fractions.

Table 2 Inhibition of yeast and mammalian a-glucosidases by the crude aqueous extracts and fractions of the fruits of F. deltoidea from two different varieties

\begin{tabular}{|c|c|c|c|c|c|c|c|}
\hline \multirow[t]{3}{*}{ Substrate } & \multicolumn{7}{|c|}{ a-glucosidases inhibitory activities, ${ } C_{50}(\mathrm{mg} / \mathrm{ml})$} \\
\hline & \multicolumn{3}{|c|}{ SF (var. angustifolia) } & \multicolumn{3}{|c|}{ BF (var. kunstleri) } & \multirow[t]{2}{*}{ Acarbose } \\
\hline & SFC & SFE & SFW & BFC & BFE & BFW & \\
\hline \multicolumn{8}{|c|}{ Yeast a-glucosidase } \\
\hline pNPG & $0.065 \pm 0.005^{a}$ & $0.259 \pm 0.014^{b}$ & $0.083 \pm 0.006^{a}$ & $0.061 \pm 0.003^{c}$ & $0.225 \pm 0.008^{d}$ & $0.049 \pm 0.003^{e}$ & $9.075 \pm 0.065$ \\
\hline \multicolumn{8}{|c|}{ Rat intestinal a-glucosidase } \\
\hline Sucrose & $0.552 \pm 0.013^{a}$ & $0.611 \pm 0.020^{a}$ & $0.473 \pm 0.011^{b}$ & $0.538 \pm 0.016^{c}$ & $0.596 \pm 0.015^{c}$ & $0.444 \pm 0.004^{d}$ & $0.039 \pm 0.001$ \\
\hline$p N P G$ & $7.226 \pm 0.389^{a}$ & $13.957 \pm 0.238^{b}$ & $7.173 \pm 0.170^{a}$ & $6.407 \pm 0.102^{c}$ & $10.040 \pm 0.291^{d}$ & $4.123 \pm 0.136^{e}$ & $0.058 \pm 0.001$ \\
\hline
\end{tabular}

Each value is expressed as a mean \pm SD of triplicates from three different experiments. Values with different superscript letters between the same variety, within the same row are significantly different at $p<0.01$. SFC, SFE and SFW indicate crude aqueous extract, ethyl acetate fraction and water fraction of SF (var. angustifolia). BFC, BFE and BFW indicate crude aqueous extract, ethyl acetate fraction and water fraction of BF (var. kuntsleri). 
Table 3 Antioxidant activities of the crude aqueous extracts and fractions of the fruits of $F$. deltoidea

\begin{tabular}{|c|c|c|c|c|c|c|c|}
\hline \multirow[t]{2}{*}{ Antioxidant assays } & \multicolumn{3}{|c|}{ SF (var. angustifolia) } & \multicolumn{3}{|c|}{ BF (var. kunstleri) } & \multirow[t]{2}{*}{ Quercetin } \\
\hline & SFC & SFE & SFW & $\mathrm{BFC}$ & BFE & BFW & \\
\hline $\begin{array}{l}\text { DPPH radical scavenging activity, } \\
{ }^{1} C_{50}(\mu \mathrm{g} / \mathrm{ml})\end{array}$ & $111.20 \pm 4.77^{a}$ & $678.18 \pm 22.31^{b}$ & $195.75 \pm 12.19^{c}$ & $150.25 \pm 3.05^{d}$ & $499.93 \pm 5.10^{e}$ & $148.02 \pm 2.25^{d}$ & $11.76 \pm 0.57$ \\
\hline $\begin{array}{l}\text { Superoxide radical scavenging } \\
\text { activity, } I_{50}(\mu \mathrm{g} / \mathrm{ml})\end{array}$ & $141.33 \pm 1.70^{a}$ & $145.15 \pm 2.92^{a}$ & $453.13 \pm 3.76^{b}$ & $153.92 \pm 0.76^{c}$ & $212.50 \pm 3.01^{d}$ & $163.78 \pm 1.98^{e}$ & $60.52 \pm 2.82$ \\
\hline $\begin{array}{l}\text { NO radical scavenging activity, } \\
\mathrm{IC}_{50}(\mathrm{mg} / \mathrm{ml})\end{array}$ & $0.79 \pm 0.01^{a}$ & $1.47 \pm 0.06^{b}$ & $1.68 \pm 0.02^{c}$ & $1.24 \pm 0.03^{d}$ & $2.02 \pm 0.06^{e}$ & $1.58 \pm 0.02^{f}$ & $101.02 \pm 1.18$ \\
\hline Ferric reducing capacity & $1.82 \pm 0.19^{a}$ & $0.34 \pm 0.11^{b}$ & $0.62 \pm 0.06^{c}$ & $1.27 \pm 0.11^{d}$ & $0.23 \pm 0.08^{e}$ & $0.77 \pm 0.08^{f}$ & $5.70 \pm 0.05$ \\
\hline \multicolumn{8}{|l|}{$\begin{array}{l}\text { (mmole of } \mathrm{Fe}^{2+} / \mathrm{g} \text { of dried } \\
\text { extract/fraction) }\end{array}$} \\
\hline $\begin{array}{l}\text { ABTS radical scavenging activity } \\
\text { (mmole Trolox/g of dried } \\
\text { extract/fraction) }\end{array}$ & $1.01 \pm 0.04^{a}$ & $0.39 \pm 0.01^{b}$ & $0.36 \pm 0.05^{b}$ & $0.88 \pm 0.07^{c}$ & $0.38 \pm 0.01^{d}$ & $0.82 \pm 0.08^{c}$ & $18.74 \pm 0.89$ \\
\hline
\end{tabular}

Each value is expressed as a mean \pm SD of triplicates from three different experiments. Values with different superscript letters between the same variety, within the same row are significantly different at $p<0.01$. SFC, SFE and SFW indicate crude aqueous extract, ethyl acetate fraction and water fraction of SF (var. angustifolia). BFC, BFE and BFW indicate crude aqueous extract, ethyl acetate fraction and water fraction of BF (var. kuntsleri).

\section{Effect of protein concentration and phenolic removal on the antidiabetic and antioxidant activities of the fruits of $F$. deltoidea}

The protein in the fruits was concentrated using ammonium sulphate and cold acetone precipitation whereas phenolics were removed with PVP. Following this treatment, the protein content of the crude extracts and water fractions increased compared to the nontreated samples (Table 4). In contrast, the phenolic content significantly decreased in samples treated with PVP. Repeated rat intestinal $\alpha$-glucosidase inhihibitory activity using sucrose as the substrate showed that the $\mathrm{IC}_{50}$ values of the fruit samples decreased significantly $(p<$ 0.05 ) compared to the nontreated samples (Table 4). On the other hand, DPPH radical scavenging assays on the treated samples resulted in significantly higher $\mathrm{IC}_{50}$ values $(p<0.01)$, indicating lower scavenging activities compared to the nontreated fruit samples.

\section{SDS-PAGE analyses of the fruits of F. deltoidea}

As shown in Figure 1, the SDS-PAGE profile of $F$. deltoidea protein fractions exhibited a clear peptide band appearing at approximately $4.4 \mathrm{kDa}$. The bands of SFC and SFW however were more distinct than those from BF samples. Each band however, might not necessarily correspond to a single protein because a few proteins with almost similar molecular weights may exist in one band.

\section{Protein detection by SELDI-TOF MS}

The SELDI-TOF MS spectra generated from the crude extracts of both varieties demonstrated different protein profiles (Figure 2A and C). BFC showed the presence of several protein peaks with $\mathrm{m} / z$ values lower than 3360 whereas SFC exhibited the opposite trend. Protein peaks corresponding to $\mathrm{m} / \mathrm{z}$ values of 3360 and 4400 were observed in both samples, however, with low relative

Table 4 Effects of protein concentration and phenolic removal on a-glucosidase and DPPH radical scavenging activities

\begin{tabular}{|c|c|c|c|c|}
\hline \multirow{2}{*}{$\begin{array}{l}\text { F. deltoidea } \\
\text { samples }\end{array}$} & \multirow{2}{*}{$\begin{array}{l}\text { Total phenolic content } \\
\text { (mg gallic acid equivalent/ } \\
\text { g sample) }\end{array}$} & \multirow{2}{*}{$\begin{array}{l}\text { Protein ( } \mu \mathrm{g} \text { protein/ } \\
\text { mg sample) }\end{array}$} & \multicolumn{2}{|l|}{$I C_{50},(\mu \mathrm{g} / \mathrm{ml})$} \\
\hline & & & $\begin{array}{l}\text { Crude a-glucosidase } \\
\text { inhibitory activity }\end{array}$ & $\begin{array}{l}\text { DPPH radical } \\
\text { scavenging activit }\end{array}$ \\
\hline \multicolumn{5}{|c|}{ SF (var. angustifolia) } \\
\hline SFC & $5.89 \pm 0.12^{a_{,}^{* * * *}}$ & $49.53 \pm 3.06^{e}$ & $348.38 \pm 20.06^{* *}$ & $547.83 \pm 18.11^{* * *}$ \\
\hline SFW & $3.98 \pm 0.07^{b, * * *}$ & $59.53 \pm 1.16^{e}$ & $396.99 \pm 16.01^{*}$ & $975.20 \pm 20.79^{* * *}$ \\
\hline $\mathrm{BFC}$ & $8.29 \pm 0.10^{c_{*}^{* * *}}$ & $70.87 \pm 1.15^{f_{*}^{*}}$ & $350.72 \pm 16.80^{* *}$ & $449.64 \pm 17.3^{* *}$ \\
\hline BFW & $6.56 \pm 0.12^{d_{1 * *}^{* *}}$ & $86.86 \pm 3.10^{9,^{* * *}}$ & $199.64 \pm 10.77^{* * *}$ & $531.17 \pm 21.59^{* * *}$ \\
\hline
\end{tabular}

Each value is expressed as a mean $\pm S D(n=3)$. Values with different superscript letters between the same variety, within the same column are significantly different at $p<0.01 .{ }^{*} p<0.05,{ }^{* *} p<0.01$ and ${ }^{* * *} p<0.001$ are significant differences from samples which were not treated with $\mathrm{PVP}^{*}\left(\mathrm{NH}_{4}\right)_{2} \mathrm{SO}_{4}$ and cold acetone. PVP: Polyvinylpyrrolidone; $\left(\mathrm{NH}_{4}\right)_{2} \mathrm{SO}_{4}$ : ammonium sulphate. SFC and SFW indicate crude aqueous extract and water fraction of SF (var. angustifolia). BFC and BFW indicate crude aqueous extract and water fraction of $\mathrm{BF}$ (var. kuntsleri). 


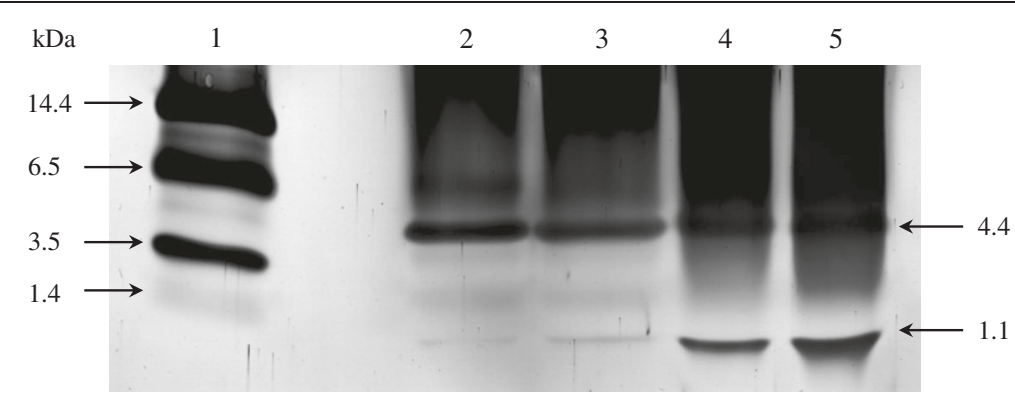

Figure 1 SDS-PAGE analysis of proteins in F. deltoidea fruit samples. Lane 1: peptide markers, lane 2: SFC - crude aqueous extract (var. angustifolia), lane 3: SFW - water fraction (var. angustifolia), lane 4: BFC - crude aqueous extract (var. kunstleri), lane 5: BFW - water fraction (var. kunstleri).

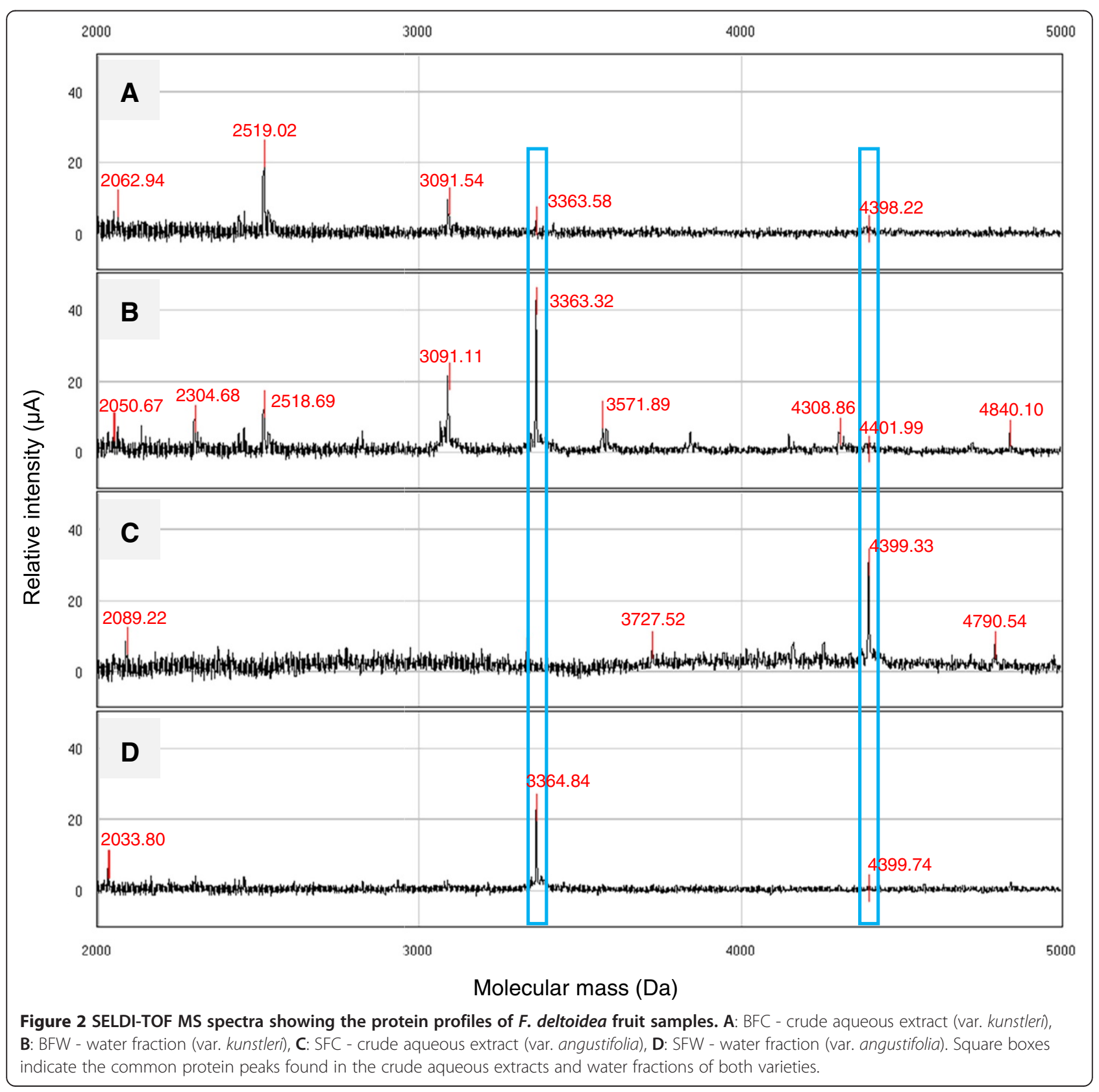


intensities. The peak at $4400 \mathrm{Da}$ coincided well with the band on SDS-PAGE but its relative intensity value did not correlate with the intensity of the band. The protein patterns of BFC displayed changes in the protein peak intensities following fractionation. Peak intensities at $\mathrm{m} / \mathrm{z}$ values of $\sim 3090,3360$ and 4400 were shown to be significantly increased. Several other peaks which were present in low abundance at $m / z \sim 2300,3500,3800$, 4100,4300 and 4800 became more apparent in BFW (Figure 2A and B). On the other hand, SF showed different protein profile whereby most of the peaks observed in SFC were absent following fractionation, with exception for a protein with $m / z 3360$.

\section{Discussion}

The antidiabetic and antioxidant activities of F. deltoidea have been reported in various studies but the part used in most of the studies was the leaf. This study was the first attempt to evaluate the ability of the fruit aqueous extracts and fractions form different varieties of $F$. deltoidea to act as antidiabetic and antioxidant agents. Partitioning of the crude aqueous extracts with ethyl acetate was aimed at separating the non-polar secondary metabolites from the highly polar compounds in the water fraction. Moreover, fractionation techniques also serves as a method of concentration of the polar components as observed in the increase of protein content in the water fraction. In general, the results of the phenolic and flavonoid contents indicated that these compounds were present at lower amounts in the aqueous extracts but could be explained by the fact that these extracts were obtained at high temperature of extraction.

Studies have reported positive correlation between phenolic content of plants and their respective antidiabetic activities $[42,43]$. In contrast to the work of Farsi et al., [19], the correlation analyses showed that phenolics and flavonoids were not directly involved in the $\alpha$-glucosidase inhibitory activities. The water fractions of both varieties of $F$. deltoidea, as a whole were better inhibitors of $\alpha$-glucosidase compared to the ethyl acetate fractions and the crude aqueous extracts. The use of acarbose as the inhibitor of $\alpha$-glucosidase and $\alpha$ amylase did not show any sign of inactivation within the range of concentration tested. This is in good agreement with other studies which stated little inhibition [44,45], or no inhibitory activity of acarbose [46-48] towards yeast $\alpha$-glucosidase. Many of the considerably potent inhibitors of baker's yeast $\alpha$-glucosidase possessed lower inhibitory activities against mammalian $\alpha$-glucosidase and is suggested to be due to the difference of molecular recognition in the binding site of the enzyme $[49,50]$. Negative inhibition values obtained for all extracts against porcine pancreatic amylase indicated that the enzyme activity was accelerated rather than suppressed.
Thus, this suggests that the glucose-lowering property of $F$. deltoidea is achieved through inactivation of $\alpha$ glucosidase but not via $\alpha$-amylase inhibition.

Studies have shown that antioxidants play a key role in reducing diabetic complications [51,52]. Furthermore, positive correlation between $\alpha$-glucosidase inhibition and antioxidant activity has been reported in numerous studies $[45,53]$. Various antioxidant assays have been developed for the estimation of antioxidative properties of plants. Ideally, a combination of assays, incorporating different mechanisms of action is useful in order to provide complete information on the antioxidant capacity of a particular plant. Fractionation of the aqueous extracts with ethyl acetate was shown to reduce the antioxidant activities. This proposes that the bioactive principles in the crude extracts may act synergistically to produce the antioxidant effect, and fractionation might have removed some of the compounds. Indeed, synergistic effects of several antioxidants in plants have been previously reported [54,55].

In order to further evaluate the effect of protein and phenolics in the fruits on antidiabetic and antioxidant activities, protein in the fruits were concentrated using ammonium sulphate and cold acetone whereas phenolics were removed using a polymer, polyvinylpyrrolidone (PVP). Ammonium sulphate precipitation is the most commonly used salt precipitation because the amount of precipitated protein will be large enough to be visible on the SDS PAGE gel. Furthermore, this technique stabilizes most proteins in the solution and reduces the lipid content resulting in a better protein profile on the gel. In the present study, the concentrated proteins were obtained in $90 \%$ saturated ammonium sulfate precipitate. On the other hand, binding of PVP to the hydroxyl group in the phenolic compounds through hydrogen bonding removes phenolics from the extracts and water fractions. The effective removal of phenolic compounds however depends on the number of hydroxyl group present that will affect the degree of PVP binding to phenolics [56]. The results indicating increased protein content as well as decreased activities of $\alpha$-glucosidase activities shown by the treated $F$. deltoidea samples strongly justified the important role of proteins in exhibiting the antidiabetic property. As statistical analyses failed to correlate phenolics and $\alpha$-glucosidase inhibitory activities, other highly polar phytochemicals may have contributed to these effects. Plant components other than phenolics, such as polysaccharides $[57,58]$ or peptides $[59,60]$ have been shown to possess antidiabetic activities and these may have contributed to the observed inhibition. It is also evident from the literature that some plants contain insulin-like peptides which give the hypoglycemic ability [61]. Apart from that, significant decreases in the phenolic contents and DPPH 
radical scavenging activities of the treated samples implies the major contribution of phenolics to the total antioxidant capacity. Correlation analyses between phenolic content and radical scavenging activities of the crude extracts, together with findings reporting positive correlation between plant phenolics and antioxidant activity [62,63], further support this observation. Although plant flavonoids have been indicated to positively correlate with antioxidant activities [64], our study found no correlation between the antioxidant activities and the amount of flavonoids in the extracts or fractions.

SDS-PAGE analysis of the proteins was carried out using Tris-tricine gel due to the low molecular weight proteins presence in the fruit samples. In addition, proteins with molecular mass lower than $20 \mathrm{kDa}$ is well suited to be profiled by SELDI-TOF MS [65]. In our study, a surface-enhanced laser desorption/ionization time of flight (SELDI-TOF)-based ProteinChip System was used for rapid identification of protein patterns in SF and BF. The reversed-phase H50 ProteinChip array used in this study binds proteins by hydrophobic interaction, thus hydrophilic proteins will not bind properly to the arrays which may lead to poor detection. The binding of proteins to the surface of the array can also be influenced by the amount of ACN in the binding buffer where higher $\mathrm{ACN}$ restricts the binding to proteins which are more hydrophobic than the buffer [65]. SELDI-TOF MS spectra showed the presence of several low molecular mass proteins in both crude extracts and their respective water fractions. The spectra is somewhat different between the two Ficus varieties, hence, could suggest the suitability of SELDI-TOF MS profiling of proteins as a new identification tool to distinguish SF from BF. Further analysis on the SELDI-TOF MS profile demonstrated that two protein peaks with the $\mathrm{m} / \mathrm{z}$ values $\sim 3360$ and 4400 are commonly found in both varieties. This finding could also serve as potential identification marker for the screening and finger-printing of $F$. deltoidea plant. In view of the antidiabetic evaluation; both water fractions demonstrated significant activity and both contained protein peaks 3360 and $4400 \mathrm{Da}$ at varying intensities. These further suggest that those low molecular mass proteins could be involved in the observed antidiabetic effect. However, the extent of their role and function requires further characterization step as well as protein identification.

\section{Conclusion}

The results obtained are in support of folklore uses of F. deltoidea in reducing blood sugar levels. Although the leaves are the parts that are traditionally used, in this study we demonstrated that both the fruit varieties also showed effective antidiabetic properties. Overall, BFW and SFW had greater antidiabetic effects compared to the corresponding crude aqueous extracts or ethyl acetate fractions, implying that compounds responsible for these activities are polar in nature. SFC was a better antioxidant than BFC and this was probably due to the phenolic compounds. Proteomics analysis by means of SDS-PAGE and SELDI-ToF demonstrated the presence of several low molecular mass proteins in the range of 3360 and $4800 \mathrm{Da}$ in the active water fractions. The involvement of carbohydrates and proteins in the fruits with the observed biological effects however, remains unclear. Animal studies are currently on going to investigate if the in vitro observations could be replicated in vivo. This would provide further information on the potential use of the fruits of $F$. deltoidea as an antidiabetic agent and their relationship with its antioxidant activity.

\section{Competing interest}

The authors declare that they have no competing interests.

\section{Authors' contributions}

$\mathrm{HM}$ performed all experimentations analysed the data and wrote the manuscript. AAA designed the antioxidant study and supervised the experimental work. NHA designed the antidiabetic, protein and proteomics studies and supervised the experimental work. All authors read and approved the final manuscript.

\section{Acknowledgements}

This present work was financially supported by the University of Malaya (UMRG-RG210-11AFR), University of Malaya Postgraduate Research Grant (PS189/2010A) and HIR/MOHE/ASH/01 (H-50001-00-A000028).

\section{Author details}

${ }^{1}$ Department of Molecular Medicine, Faculty of Medicine, University of Malaya, 50603, Kuala Lumpur, Malaysia. ${ }^{2}$ University Malaya Centre for Proteomics Research (UMCPR), Medical Biotechnology Laboratory, Faculty of Medicine, University of Malaya, 50603, Kuala Lumpur, Malaysia. ${ }^{3}$ Institute of Biological Sciences, Faculty of Science, University of Malaya, 50603, Kuala Lumpur, Malaysia.

Received: 8 February 2013 Accepted: 23 May 2013

Published: 29 May 2013

\section{References}

1. Teixeira CC, Rava CA, Da-Silva PM, Melchior R, Argenta R, Anselmi F, Almeida $C R$, Fuchs FD: Absence of antihyperglycemic effect of jambolan in experimental and clinical models. J Ethnopharmacol 2000, 71:343-347.

2. Youn J, Park H, Cho K: Anti-hyperglycaemic activity of Commelina communis L.: inhibition of a-glucosidase. Diabetic Res Clin Prac 2004, 665:S149-S155.

3. Saito N, Sakai H, Sekihara H, Yajima Y: Effect of a-glucosidase inhibitor (voglibose), in combination with sulphonylureas, on glycaemic control in type 2 diabetes patients. J Int Med Res 1998, 26:219-232.

4. Bhandari MR, Jong-Anurakkhun N, Hong G, Kawabata J: a-glucosidase and a-amylase inhibitory activities of Napalese medicinal herb Pakhanbhed (Bergenia ciliata, Haw). Food Chem 2008, 106:247-252.

5. Rhabasa-Lhoret R, Chiasson JL: Glucosidase inhibitors. In International Textbook of Diabetes Mellitus. 3rd edition. Edited by Defronzo RA, Ferrannini E, Keen H, Zimmet P. UK: John Wiley \& Sons Ltd; 2004. 1: 901-914.

6. Bonnefont-Rousselot D, Bastard JP, Jaudon MC, Delattre J: Consequences of the diabetic status on the oxidant/antioxidant balance. Diabetes Metab 2000, 26:163-176.

7. Ceriello A: Oxidative stress and diabetes-associated complications. Endocr Pract 2006, 12:60-62.

8. Rains JL, Jain SK: Oxidative stress, insulin signaling and diabetes. Free Radic Biol Med 2011, 50:567-575. 
9. Pasupathi P, Rao YY, Faook J, Saravanan G, Bakthavathsalam G: Oxidative stress and cardiac biomarkers in patients with acute myocardial infarction. Eur J Sci Res 2009, 27:275-285.

10. Calabrese V, Mancuso C, Sapienza M, Puleo E, Calafato S, Cornelius C, Finocchiaro M, Mangiameli A, Di-Mauro M, Giuffrida Stella AM, Castellino P. Oxidative stress and cellular stress response in diabetic nephropathy. Cell Stress Chaperones 2007, 12:299-306.

11. Grover JK, Yadav S, Vats V: Medicinal plants of India with antidiabetic potential. J Ethnopharmacol 2002, 81:81-100.

12. Manickam M, Ramanathan M, Jahromi MA, Chansouria JP, Ray AB: Antihyperglycemic activity of phenolics from Pterocarpus marsupium. J Nat Prod 1997, 60:609-610.

13. Panda S, Kar A: Apigenin (4',5,7-trihydroxyflavone) regulates hyperglycaemia, thyroid dysfunction and lipid peroxidation in alloxaninduced diabetic mice. J Pharm Pharmacol 2007, 59:1543-1548.

14. Yoshikawa M, Wang T, Morikawa T, Xie H, Matsuda H: Bioactive Constituents from Chinese Natural Medicines XXIV Hypoglycemic Effects of Sinocrassula indica in Sugar-Loaded Rats and Genetically Diabetic KKAy Mice and Structures of New Acylated Flavonol Glycosides, Sinocrassosides A1, A2, B1, and B2. Chem Pharm Bull 2007, 55:1308-1315.

15. Dineshkumar B, Mitra A, Mahadevappa M: Antidiabetic and hypolipidemic effects of mahanimbine (carbazole alkaloid) from murraya koenigii (rutaceae) leaves. Int J Phytomed 2010, 2:22-30.

16. Sharma B, Salunke R, Balomajumder C, Daniel S, Roy P: Anti-diabetic potential of alkaloid rich fraction from Capparis decidua on diabetic mice. J Ethnopharmacol 2010, 127:457-462.

17. Tan MJ, Ye JM, Turner N, Hohnen-Behrens C, Ke CQ, Tang CP, Chen T, Weiss $H C$, Gesing ER, Rowland A, James DE, Ye Y: Antidiabetic activities of triterpenoids isolated from bitter melon associated with activation of the AMPK pathway. Chem Biol 2008, 15:263-273.

18. Contreras C, Roman R, Perez C, Alarcon F, Zavala M, Perez S: Hypoglycemic activity of a new carbohydrate isolated from the roots of Psacalium peltatum. Chem Pharm Bull 2005, 53:1408-1410.

19. Farsi E, Shafaei A, Sook YH, Khadeer Ahamed BM, Mun FY, Idress HA, Zaini $M A$, Ismail Z: Correlation between enzymes inhibitory effects and antioxidant activities of standardized fractions of methanolic extract obtained from Ficus deltoidea leaves. Afr J Biotechnol 2011, 10:15184-15194.

20. Choo CY, Sulong NY, Man F, Wong TW: Vitexin and isovitexin from the Leaves of Ficus deltoidea with in-vivo a-glucosidase inhibition. $J$ Ethnopharmacol 2012, 142:776-781.

21. Omar MH, Mullen W, Crozier A: Identification of proanthocyanidin dimers and trimers, flavone C-Glycosides, and antioxidants in Ficus deltoidea, a Malaysian herbal tea. J Agric Food Chem 2011, 59:1363-1369.

22. Adam Z, Khamis S, Ismail A, Hamid M: Ficus deltoidea: A potential alternative medicine for diabetes mellitus. Evidence-Based Complementary Altern Med 2012, 201(2):632763

23. Armaghan S, Elham F, Khadeer BMH, Jamshid MAS, Idress HA, Ismail Z, Zaini MA: Evaluation of toxicological and standardization parameter and phytochemical investigation of Ficus deltoidea. Am J Biochem Mol Biol 2011, 1:237-243

24. Adam Z, Hamid M, Ismail A, Khamis S: Effect of Ficus deltoidea aqueous extract on blood glucose level in normal and mild diabetic rats. Malaysian J Health Sci 2007, 5:9-16.

25. Aminudin N, Chung YS, Eue SC, Kang IN, Lee R: Blood glucose lowering effect of Ficus deltoidea aqueous extract. Malaysian J Sci 2007, 26:73-78.

26. Adam Z, Khamis S, Ismail A, Hamid M: Inhibitory properties of Ficus deltoidea on a-glucosidase activity. Res J Med Plant 2010, 4:61-75.

27. Sulaiman MR, Hussain MK, Zakaria ZA, et al: Evaluation of the antinociceptive activity of Ficus deltoidea aqueous extract. Fitoterapia 2008, 79:557-561.

28. Siti Fatimah Zahra MA, Mahmood AA, Hapipah MA, Suzita MN, Salmah I: Anti-ulcerogenic activity of aqueous extract of Ficus deltoidea against ethanol-induced gastric mucosal injury in rats. Res J Med Sci 2009, 3:42-46.

29. Hakiman M, Maziah M: Non enzymatic and enzymatic antioxidant activities in aqueous extract of different Ficus deltoidea accessions. J Med Plants Res 2009, 3:120-131.

30. Abdullah Z, Hussain K, Zhari I, Rasadah MA, Mazura P, Jamaludin F, Sahdan R: Evaluation of extracts of leaf of three Ficus deltoidea varieties for antioxidant activities and secondary metabolites. Pharmacogn Res 2009, $1: 216-223$.
31. Zakaria ZA, Hussain MK, Mohamad AS, Abdullah FC, Sulaiman MR: Antiinflammatory activity of the aqueous extract of Ficus deltoidea. Biol Res Nurs 2012, 14:90-97

32. Oh MJ, Abdul Hamid M, Ngadiran S, Seo YK, Sarmidi MR, Park CS: Ficus deltoidea (Mas cotek) extract exerted anti-melanogenic activity by preventing tyrosinase activity in vitro and by suppressing tyrosinase gene expression in B16F1 melanoma cells. Arch Dermatol Res 2011, 303:161-170.

33. Singleton UL, Rossi J: Colorimetry of total phenolics with phosphomolybdicposphotungustic acid reagent. Am J Enol Vit 1965, 16:144.

34. DuBois MK, Gils JK, Hanniton PA, Robes, Smith F: Use of phenol reagent for the determination of total sugar. Anal Chem 1956, 28:350.

35. Bradford MM: A rapid and sensitive method for the quantitation of microgram quantities of protein utilizing the principle of protein-dye binding. Anal Biochem 1976, 72:248-254.

36. Braca A, Tommasi ND, Bari LD, Pizza C, Politi M, Morelli I: Antioxidant principles from Bauhinia terapotensis. J Nat Prod 2001, 64:892-895.

37. Benzie IFF, Strain JJ: Ferric reducing ability of plasma (FRAP) as a measure of antioxidant power: the FRAP assay. Anal Biochem 1996, 239:70-76.

38. Nishikimi M, Appaji N, Yagi K, et al: The occurrence of superoxide anion in the reaction of reduced phenazine methosulfate and molecular oxygen. Biochem Biophys Res Commun 1972, 46:849-854.

39. Sindhu RK, Griffin DH, Walton DC: Abscisic aldehyde is an intermediate in the enzymatic conversion of xanthoxin to abscisic acid in Phaseolus vulgaris L leaves. Plant Physiol 1990, 93:689-694.

40. Laemmli UK: Cleavage of structural proteins during the assembly of the head of bacteriophage T4. Nature 1970, 227:680-685.

41. Lau BF, Aminudin N, Abdullah N: Comparative SELDI-TOF-MS profiling of low-molecular-mass proteins from Lignosus rhinocerus (Cooke) Ryvarden grown under stirred and static conditions of liquid fermentation. $J$ Microbiol Methods 2011, 87:56-63.

42. Anam K, Widharna RM, Kusrini D: a-glucosidase inhibitor activity of Terminalia species. Int J Pharmacol 2009, 5:277-280.

43. Momo CEN, Fuh Ngwa A, Dongmo GIF, Oben JE: Antioxidant properties and a amylase inhibition of Terminalia superba Albizia sp., Cola nitida, Cola odorata and Harungana madagascarensis used in the management of diabetes in Cameroon. J Health Sci 2009, 55:732-738.

44. Oki T, Matsui O, Osajima Y: Inhibitory effect of alpha-glucosidase inhibitors varies according to its origin. J Agric Food Chem 1999, 47:550-553.

45. Shai $L$, Masoko P, Mokgotho MP, Magano SR, Mogale AM, et al: Yeast alpha glucosidase inhibitory and antioxidant activities of six medicinal plants collected in Phalaborwa, South Africa. South Afr J Bot 2010, 76:465-470.

46. Kim JS, Kwon CS, Son KH: Inhibition of alpha-glucosidase and amylase by luteolin, a flavonoid. Biosci Biotechnol Biochem 2000, 64:2458-2461.

47. Kim YM, Wang $\mathrm{MH}$, Rhee $\mathrm{HI}$ : A novel alpha-glucosidase inhibitor from pine bark. Carbohydr Res 2004, 339:715-717

48. Schafer A, Hogger P: Oligomeric procyanidins of French maritime pine bark extract $\left(\right.$ Pycnogenol $\left.^{\oplus}\right)$ effectively inhibit a-glucosidase. Diabetes Res Clin Pract 2007, 77:41-46.

49. Iwai K: Antidiabetic and antioxidant effects of polyphenols in brown alga Ecklonia stolonifera in genetically diabetic KK-A $\mathrm{A}^{\mathrm{y}}$ mice. Plant Foods Hum Nutr 2008, 63:163-169.

50. Gao H, Kawabata J: a-glucosidase inhibition of 6-hydroxyflavones. Part 3: synthesis and evaluation of 2,3,4-trihydroxybenzoyl-containing flavonoid analogs and 6-aminoflavones as a-glucosidase inhibitors. Bioorg Med Chem 2005, 13:1661-1671.

51. Rahimi R, Nikfar S, Larijani B, Abdollahi M: A review on the role of antioxidants in the management of diabetes and its complications. Biomed Pharmacother 2005, 59:365-373.

52. Tchinda AT, Tchuendem MH, Khan SN, Omar I, Ngandeu F, Nkeng PEA Choudhary IM: Antioxidant activity of the crude extract of the fruits of Pycnanthus angolensis and a-glucosidase inhibitory activity of its constituents. Pharmacologyonline 2008, 1:422-431.

53. Yao Y, Sang W, Zhou M, Ren G: Antioxidant and alpha-glucosidase inhibitory activity of colored grains in China. J Agric Food Chem 2010, 58:770-774.

54. Wu N, Fu K, Fu YJ, Zu YG, Chang FR, Chen YH, Liu XL, Kong Y, Liu W, Gu CB: Antioxidant Activities of Extracts and Main Components of Pigeonpea [Cajanus cajan (L) Millsp] Leaves. Molecules 2009, 14:1032-1043. 
55. Jain DP, Pancholi SS, Patel R: Synergistic antioxidant activity of green tea with some herbs. J Adv Pharm Technol Res 2011, 2:177-183.

56. Carpenter A, Siggia S, Carter S: Separation and/or Concentration of phenolic materials from dilute aqueous solutions. Anal Chem 1976, 48:225-228.

57. Azevedo CR, Maciel FM, Silva LB, Ferreira AT, Da-Cunha M, Machado OL, Fernandes KV, Oliveira AE, Xavier-Filho J: Isolation and intracellular localization of insulin-like proteins from leaves of Bauhinia variegate. Braz J Med Biol Res 2006, 39:1435-1444.

58. Yuan X, Gu X, Tang J: Purification and characterisation of a hypoglycemic peptide from Momordica Charantia L. Var abbreviata Ser. Food Chem 2008, 111:415-420.

59. Fenglin L, Qingwang L, Dawei G, Yong P, Caining F: Preparation and antidiabetic activity of polysaccharide from Portulaca oleracea $L$. Afr $J$ Biotechnol 2009, 8:569-573.

60. Kim HM, Kang JS, Kim JY, Park SK, Kim HS, Lee YJ, Yun J, Hong JT, Kim Y, Han SB: Evaluation of antidiabetic activity of polysaccharide isolated from Phellinus linteus in non-obese diabetic mouse. Int Immunopharmacol 2010, 10:72-78.

61. Paul A, Raychaudhuri SS: Medicinal uses and molecular identification of two Momordica charantia varieties - a review. Electron J Biol 2010, 6:43-51.

62. Kim H, Choi H, Moon J, Kim Y, Mosaddik A, Cho S: Comparative antioxidant and antiproliferative activities of red and white pitayas and their correlation with flavonoid and polyphenol content. J Food Sci 2010 76:C38-C45.

63. Razab A, Abdul Aziz A: Antioxidants from tropical herbs. Nat Prod Commun 2010, 5:441-445.

64. Sariburun E, Sahin S, Demir C, Turkben C, Uylaser V: Phenolic content and antioxidant activity of raspberry and blackberry cultivars. J Food Sci 2010, 75:C328-C335

65. Papale M, Pedicillo MC, Thatcher BJ, Di-Paolo S, Lo Muzio L, Bufo P, Rocchetti MT, Centra M, Ranieri E, Gesualdo L: Urinary profiling by SELDITOF/MS: monitoring of the critical steps in sample collection, handling and analysis. J Chromatogr B 2007, 856:205-213.

doi:10.1186/1472-6882-13-118

Cite this article as: Misbah et al:: Antidiabetic and antioxidant properties of Ficus deltoidea fruit extracts and fractions. BMC Complementary and Alternative Medicine 2013 13:118.

\section{Submit your next manuscript to BioMed Central and take full advantage of:}

- Convenient online submission

- Thorough peer review

- No space constraints or color figure charges

- Immediate publication on acceptance

- Inclusion in PubMed, CAS, Scopus and Google Scholar

- Research which is freely available for redistribution 